\title{
Preliminary impact of IFRS 9 implementation on the Lebanese banking sector
}

\author{
Darine Dib $^{1, \mathrm{a}}$ and Khalil Feghali ${ }^{\mathrm{a}}$ \\ ${ }^{a}$ Faculty of Economics and Business Administration, Lebanese University, \\ Lebanon
}

\begin{abstract}
Research Question: What is the impact of the new requirements of the expected credit loss (ECL) model on the Lebanese banking sector?

Motivation: In spite the expansion of research in respect of International Financial Reporting Standard N0. 9 (IFRS 9) in the past few years, it is still in its infancy in developing countries. Meanwhile, empirical IFRS 9 studies for banks is yet considered little as compared to the theoretical aspect. Our study seeks to fill this gap by testing the impact of IFRS 9 on the Lebanese banking sector. This paper is the first comprehensive attempt to empirically assess the estimated impact of IFRS 9 as disclosed in the 2017 financial statements.
\end{abstract}

Idea: This study examines if the increase in provision based on the new ECL is strongly positively related to the average credit losses for the last 5 years, the current provisions level for the loans portfolio, the portfolio of investment securities, and the portfolio of liquid assets.

Data: The data were collected from 19 consolidated banks representing $91 \%$ of the total consolidated balance sheet of all Lebanese banks.

Tools: To test study's hypotheses, we applied linear regression using SPSS.

Findings: Two main results can be derived: First, we found that the impact of the new ECL model is not material to the banks' equity if we consider the excess regulatory provisions booked in anticipation of IFRS 9. Second, we found that the increase in provision based on the ECL model is strongly positively related to the portfolio of investments securities and negatively related to the historical credit loss ratio.

Contribution: Empirical IFRS 9 studies for banks is yet considered little as compared to the theoretical aspect. Our study seeks to fill this gap by testing the impact of IFRS 9 on the Lebanese banking sector. The Lebanese banks are an interesting case because they play a key

${ }^{1}$ Corresponding author: Darine Dib, Faculty of Economics and Business Administration, Lebanese University, Lebanon, Tel. (+961) 3 159248, email addresses: darinedib@ hotmail.com 
role in the Lebanese economy, acting as the main channel for capital inflows into the country and financing the largest part of the government's current account deficit.

Keywords: IFRS 9, Expected Credit Loss (ECL), Incurred Loss, Classification and measurement.

\section{JEL codes: M41}

\section{Introduction}

After many years of preparation, the International Accounting Standards Board (IASB) issued the final version of IFRS 9 Financial Instruments (applicable starting 2018) in July 2014, completely replacing IAS 39 Financial Instruments and all previously issued versions of IFRS 9 (2009, 2010, and 2013). The final standard introduced new requirements for classification and measurement of financial assets and liabilities, impairment, and hedge accounting.

Banks operating in Lebanon applied the IFRS 9 requirements as issued by the IASB during November 2009 (which addressed specifically the classification and measurement of financial assets). In accordance with the requirements of the standard, the Central Bank of Lebanon circular no. 143, and the Banking Control Commission circular no. 293, Lebanese banks applied IFRS 9 on 1 January 2018. In addition, Lebanese banks disclosed the assessment of the estimated impact of IFRS 9 implementation on the banks' equity in their financial statements for the year ending 31 December 2017.

IFRS 9 has tremendously changed the way banks accounts for their financial assets and provisions. The expected impact of the new standard on banks' equity has become a concern and a significant challenge for the different stakeholders due to its potentially large expected negative impact on the banks' position, performance, and solvency. Large audit firms and regulators have issued several surveys to assess the expected impact of the IFRS 9 adoption (refer to table 2). Initial studies showed a more than $50 \%$ increase in the level of provisioning, while later studies showed a lesser but material expected increase. Most studies explored the theoretical aspect of the new standard or the change between IAS 39 and IFRS 9 (Ghasmi, 2016; Novotny-Farkas, 2016; Gornjak, 2017).

In spite the expansion of research in respect of IFRS 9 in the past few years, it is still in its infancy in developing countries. Meanwhile, empirical IFRS 9 studies for banks is yet considered little as compared to the theoretical aspect. Consequently, a research to convey insights regarding the banking sector in developing countries is needed. Therefore, this study aims to investigate the impact of IFRS 9 on Lebanese 
banks. The Lebanese banks are an interesting case because they play a key role in the Lebanese economy, acting as the main channel for capital inflows into the country and financing the largest part of the government's current account deficit. In addition, during the last years, the balance sheet of the Lebanese banks increased by $18 \%$ between 2016 and 2018. As far as we know, no studies were performed in Lebanon to empirically assess the estimated impact of IFRS 9 as disclosed in the 2017 financial statements. In addition, we are not aware of previous Lebanese studies that developed models to predict the ECL impact based on a certain number of independent variables extracted from financial statements.

Our objective is to assess the impact of the new requirements for impairment on the Lebanese banking sector. We hypothesize that the impact of the new expected loss model is material to the banks' accounts. In addition, we hypothesize that the increase in provision based on the new ECL is strongly positively related to the average credit losses for the last 5 years, the current provisions level for the loans portfolio, the portfolio of investment securities, and the portfolio of liquid assets.

We hope this paper, as one of the earliest attempts to measure the impact of IFRS 9, contributes to the banking industry. To the best of our knowledge, prior publications (other than surveys) about the impact of IFRS 9 in Lebanon as of its date of adoption are virtually non-existent. Our aim is to provide initial evidence confirming or rejecting the belief that IFRS 9 will result in a material adjustment on the Lebanese banks' equity as of 1 January 2018. In addition, our aim is to provide the market with a robust model that could predict ECL impact as of 1 January 2018.

The rest of this paper is organized as follows: Section 2 provides a brief explanation about IFRS 9 and the new ECL model. Section 3 presents some information about the Lebanese banking sector. Section 4 develops the different hypotheses, and Section 5 outlines the research method used to test them. Section 6 presents the results, and Section 7 analyses them in detail. Section 8 concludes the paper by discussing the implications and limitations of the study as well as areas for further research.

\section{IFRS 9 implementation}

\subsection{IFRS 9 briefing and adoption in Lebanon}

We start by introducing the IFRS 9 standard, its phases, and its adoption in Lebanon.

In 2001, the IASB approved and adopted IAS 39 Financial Instruments: Recognition and Measurement. The financial crisis highlighted the need to strengthen accounting recognition of credit losses, among others (Salhi \& Thérond, 2017). In 2009, the IASB launched the IFRS 9: Financial Instruments project to fully replace IAS 39. However, the project had to be divided into three main phases due to requests for 
immediate improvement in the accounting of financial instruments. Once each phase was completed, the IASB issued chapters in IFRS 9 substituting the equivalent section of IAS 39 (IFRS Foundation, 2014). The significant dates of the process are presented in table 1 below:

Table 1. IFRS 9 major dates

\begin{tabular}{|c|c|c|}
\hline Date & Area & Description \\
\hline November 2009 & $\begin{array}{l}\text { Financial assets/classification } \\
\text { and measurement }\end{array}$ & $\begin{array}{l}\text { The IASB approved and issued the chapters dealing with the the classification and measurement of } \\
\text { financial assets. }\end{array}$ \\
\hline October 2010 & $\begin{array}{l}\text { Financial liabilities/classification } \\
\text { and measurement }\end{array}$ & The requirements relating to the classification and measurement of financial liabilities were added. \\
\hline October 2010 & $\begin{array}{l}\text { Financial assets \& } \\
\text { liabilities/derecognition }\end{array}$ & $\begin{array}{l}\text { The IASB decided to leave the derecognition of financial assets and financial liabilities intact as it was } \\
\text { previously unde IAS } 39 \text {. }\end{array}$ \\
\hline December 2011 & Effective date of IFRS 9 & The IASB delayed the madatory effective date of implementation of the standard. \\
\hline November 2013 & Hedge accounting & The IASB added the Hedge Accounting chapter. \\
\hline July 2014 & Complete version & The full version of IFRS 9 standard was issued with an effective application date as of 1 January 2018 \\
\hline October 2017 & $\begin{array}{l}\text { Financial assets with } \\
\text { prepayment } \\
\text { features/classification \& } \\
\text { measurement }\end{array}$ & $\begin{array}{l}\text { IFRS } 9 \text { was amended by Prepayment Features with Negative Compensation. Effective date } 1 \text { January } \\
2019 .\end{array}$ \\
\hline
\end{tabular}

As shown in the table, in July 2014, the IASB issued the full version of the standard with an effective application date of 1 January 2018 and early adoption permission. In its final version, the IASB made slight changes to the classification and measurement requirements for financial assets, mainly by introducing a new category - fair value through other comprehensive income. The IASB also added the accounting for ECL requirements on financial assets and other commitments to grant/prolong credit (IFRS Foundation, 2014).

In accordance with the Banking Control Commission requirements under its intermediate circular no. 265, banks in Lebanon were required to early adopt IFRS 9 (2009), which included only the classification and measurement of financial assets (BCCL, 2010), on 1 January 2011. From 2011 to 2013, some Lebanese banks early adopted the IFRS 9 versions IFRS 9 (2011) and IFRS 9 (2013), which included the requirements for classification and measurement of financial liabilities and the hedge accounting requirements, respectively. Based on the standard's requirement, banks in Lebanon had to adopt the complete version of IFRS 9 on 1 January 2018. The Central Bank of Lebanon issued circular no.143 on 7 November 2017, which emphasized the requirement to apply IFRS 9 and requested banks to prepare for its adoption by 31 December 2017 (CBL, 2017). In turn, the Banking Control Commission issued a separate circular, no. 293, on 30 December 2017, offering application guidance for IFRS 9: staging criteria, governance, reporting, classification, ECL and so on (BCCL, 2017).

As per IAS 8: Accounting Policies, Changes in Accounting Estimates and Errors, a company should account for a change in accounting policy as a result of the initial 
application of an IFRS in accordance with the specific transitional provision of that standard (IFRS Foundation, 2003). As mentioned in the transition provisions of IFRS 9 (2014), a company can choose not to restate comparative figures. Any amendments required on the carrying values of financial assets and liabilities at the date of transition as a result of IFRS 9 adoption can be recognized in the opening equity of the period when IFRS 9 was adopted (PwC, 2017).

In addition, as per IAS 8, when a new IFRS standard is issued but is not yet effective, a company that has not early applied it should disclose known or reasonably estimable information to evaluate the possible impact of this new standard on the financial statements. This means that a company should include a discussion of the impact of the initial application of the new standard or a declaration explaining that the impact is not yet known or reasonably estimable (IFRS Foundation, 2003) in the financial statements of the period prior to the adoption date. Since the application date of IFRS 9 was 1 January 2018, entities were expected to have known and disclosed the new standard's impact on the 2017 financial statements. This applied to Lebanese banks that, theoretically, should have disclosed the quantitative assessment of the IFRS 9 adoption in their 2017 financial statements.

In the following sub-section, we will discuss the main requirements of IFRS 9 new expected credit loss model.

\subsection{Expected credit loss (ECL)}

The practice in IAS 39 used incurred losses arising from past events. Accordingly, future credit loss events, even when expected, were not considered (Salhi \& Thérond, 2017) leading to criticism for deferring the recognition of provisions until too late (Hoogervorst, 2014). Impairment was assessed using a "what has happened" methodology; however, while trying to answer concerns over "too little too late" provisioning for loan losses, IFRS 9 moved to a forward-looking "expected loss" model. Impairment decisions are now based on the loss expected.

According to the ECL model, entities need to incorporate not only the historical and current data but also reasonable information including forecasts of future economic conditions. The new model requires an impairment provision to be recorded on the first day, "Day 1" (KPMG, 2015). "Methodological and stochastic concepts of credit risk, previously mostly used in internal steering, in regulatory context and in modeling economic capital, is entering the area of accounting with the new ECL model" (Reitgruber, 2015).

IFRS 9 requires earlier and larger impairment allowances and is expected to increase the credit loss allowances of many companies, particularly banks; however, the magnitude will vary depending on past practice. "Entities with shorter term and higher quality assets are likely to be less significantly affected" (Ernest \& Young, 
2018). In a study over the 18 biggest banks in Europe by total assets, Orban and Tamimi (2020) found that the new amendment related to the impairment of financial instruments under IFRS 9 has no significant impact on the total amount of ECL for these banks however the ECL vary by country.

Abad and Suarez (2017) found that provisions for credit losses under IFRS 9 are about 152 basis points higher than under IAS 39. Csaba (2017) found that IFRS 9 recognizes loan loss provision earlier and with a higher amount then IAS 39.

The ECL on existing non-impaired assets would necessarily decrease bank earnings on the date of IFRS 9 implementation. As explained by O'Hanlon, Hashim and Li (2015) this immediate decrease of the book value of such financial assets would result in "day-one losses".

In an attempt to assess the impact of the application of the new ECL requirements, KPMG (2018) analyzed the financial statements of 56 listed commercial banks in the GCC countries. KPMG found that on the date of initial application of the ECL, (i) the impairment provision increased by $30.2 \%$ in IFRS 9 compared to IAS 39 and (ii) Common Equity Tier 1 (CET1) decreased by an average of 90 basis points (bps). The increase in impairment provision ranked between 5.6\% (the lowest increase was found in Oman) and 44.1\% (the highest increase was found in Saudi Arabia).

Based on analyzing the data of surveys conducted by the European Banking Industry and by the Banking Regulation and Supervision Agency (BRSA) in Turkey during 2016 and 2017, Sultanoğlu (2018) expected that, ECL application by European banks would result in an average increase in loss provisions by $13 \%$ to $18 \%$ compared to an average decrease by $4.1 \%$ for Turkish banks. Furthermore, he expected that CET1 and total capital ratio for European banks will decrease by on average of 45 to $75 \mathrm{bps}$ and 35 to $50 \mathrm{bps}$, respectively compared to an average increase of $33 \mathrm{bps}$ and $21 \mathrm{bps}$ of CET1 and total capital adequacy ratio respectively for Turkish banks. Sultanoğlu further explained that Turkish banks will face reverse impacts upon IFRS 9 implementation as a result of the application of specified rate for calculating general and specific provision as required by the Turkish regulator.

The new rules will probably modify the behavior of banks during periods of credit recession, theoretically reducing procyclicality (Cohen \& Edwards, 2017, Kund \& Rugilo, 2018, Lu \& Nikolaev, 2019). In the long term, IFRS 9 should improve credit risk management and internal processes of price determination which would improve financial stability (Hoogervorst, 2016, Kund \& Rugilo, 2018, Tominac \& Vašiček, 2018, Gornjak 2020). IFRS 9 will reduce the overstatement of equity in flourishing periods and the understatement of equity in downturns. In fact, IFRS 9 has been assessed as having a positive impact on shareholder wealth (Onali \& Ginesti, 2014). Szücs and Márkus (2020) found that changes in impairment had a significant impact on stock exchange rates. On the other hand, Ertan (2019) found that the ECL approach has adverse effects on the credit access of small businesses. "For these 
entities, the new rules seem to reduce credit amounts and loan maturities, while increasing interest costs and collateral requirement".

However, other researchers found that companies will use IFRS 9 to smooth their earnings. Casta el $\mathrm{Al}$ (2019) found that "banks have incentive to decrease (increase) their level of discretionary loan loss provisions when unfavorable impact on retained earnings is higher (lower), supporting the income smoothing hypothesis". "The ECL model provides significant room for managerial discretion" (Novotny-Farkas, 2016) over the timing and measurement of expected losses. In a case study of a Greek government bond for the period from 2009 to 2011, Gebhardt (2016) highlights the discretion management have when estimating impairments. He founds that management may arrive at different conclusions when applying judgment required by IFRS 9. In addition, he found that IFRS 9 will lead to earlier impairments compared to IAS 39.

Seitz et al. (2018) found that the new ECL should exceed the levels of IAS 39 provisions during the crisis but in a normal business, the loan reserves are not generally higher. In addition, provisions are very volatile as a result of the changes in the market conditions and parameters as well as across EU countries and regions. The research pointed further to the high sensitivity of the ECL to the probability of default (PD) models created. The paper suggest that IFRS 9 provision are not likely to result in increase in countercyclical loan loss reserves.

In a study performed by Gornjak (2020), the author concluded that during a period of good economic condition, the impact of ECL should be lower than during a downturn since lifetime ECL should be recognized instead of 12-month ECL when credit risk deteriorates.

The new impairment model applies to financial assets measured at amortised cost (AC) or fair value through other comprehensive income (FVOCI), including offbalance sheet commitments (loans commitments, letters of credit, letters of guarantees).

Under the general approach, ECL is recognized on credit exposures in three stages:

- Stage 1: for balances where there has not been a significant increase in credit risk (SICR) since initial recognition, companies should provide for ECL that result from default events 'that are possible' within the next 12 months.

- Stage 2: for balances where a SICR occurred since initial recognition, companies should provide for ECL resulting from the default expected over the remaining life of the exposure.

- Stage 3: for financial assets that are assessed as credit-impaired, companies must use the same criteria for the individual impairment assessment under IAS 39 (Ernst \& Young, 2018). 
Figure 1 shows the three stages of the general model of impairment as presented by Deloitte (2016):

\section{Figure 1: General Model of the Impairment of the Financial Assets} Source: Deloitte, 2016

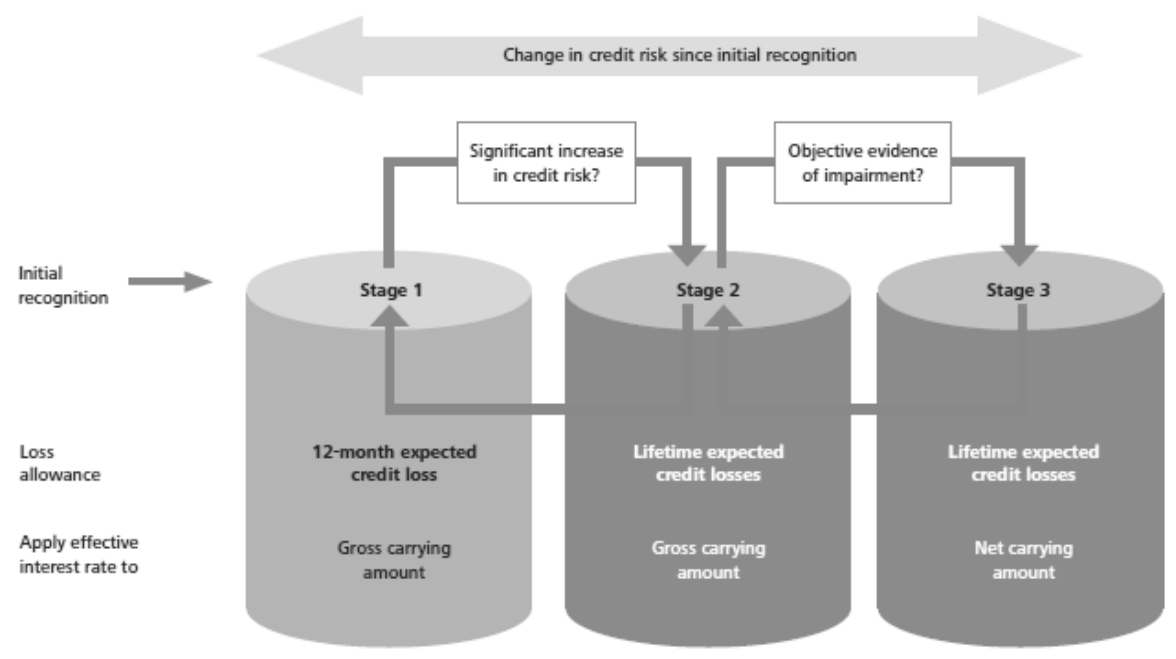

As shown in the graph, the new ECL requirements brings more impairment loss as a result of the ECL on financial assets classified in Stage 1 and 2. Impairment allowances for Stage 3 under IFRS 9 and IAS 39 are considered to be exactly the same.

A substantial level of judgment is required when applying the requirements for computing ECL in many aspects, such as determining (PwC, 2017):

- the quantitative and qualitative principles for SICR;

- the correct statistical models and assumptions for the measurement of ECL;

- the number of forward-looking scenarios and probability weight assigned to them; and

- the appropriate grouping/non-grouping of financial assets when collectively measuring the ECL.

Hence, judgement is increased under IFRS 9 compared to the incurred loss model where a credit loss is based mainly on an actual loss event (Frykström \& Li, 2018). "IFRS 9 changes the relationship between non performing loans and provisions, by relying on greater judgement to determine provisions." (Bholat et al., 2018). 


\subsection{Previous studies}

Summarized in table 2 below are the results of several surveys concerning the impact of IFRS 9.

Table 2. Results of surveys on IFRS 9 impact

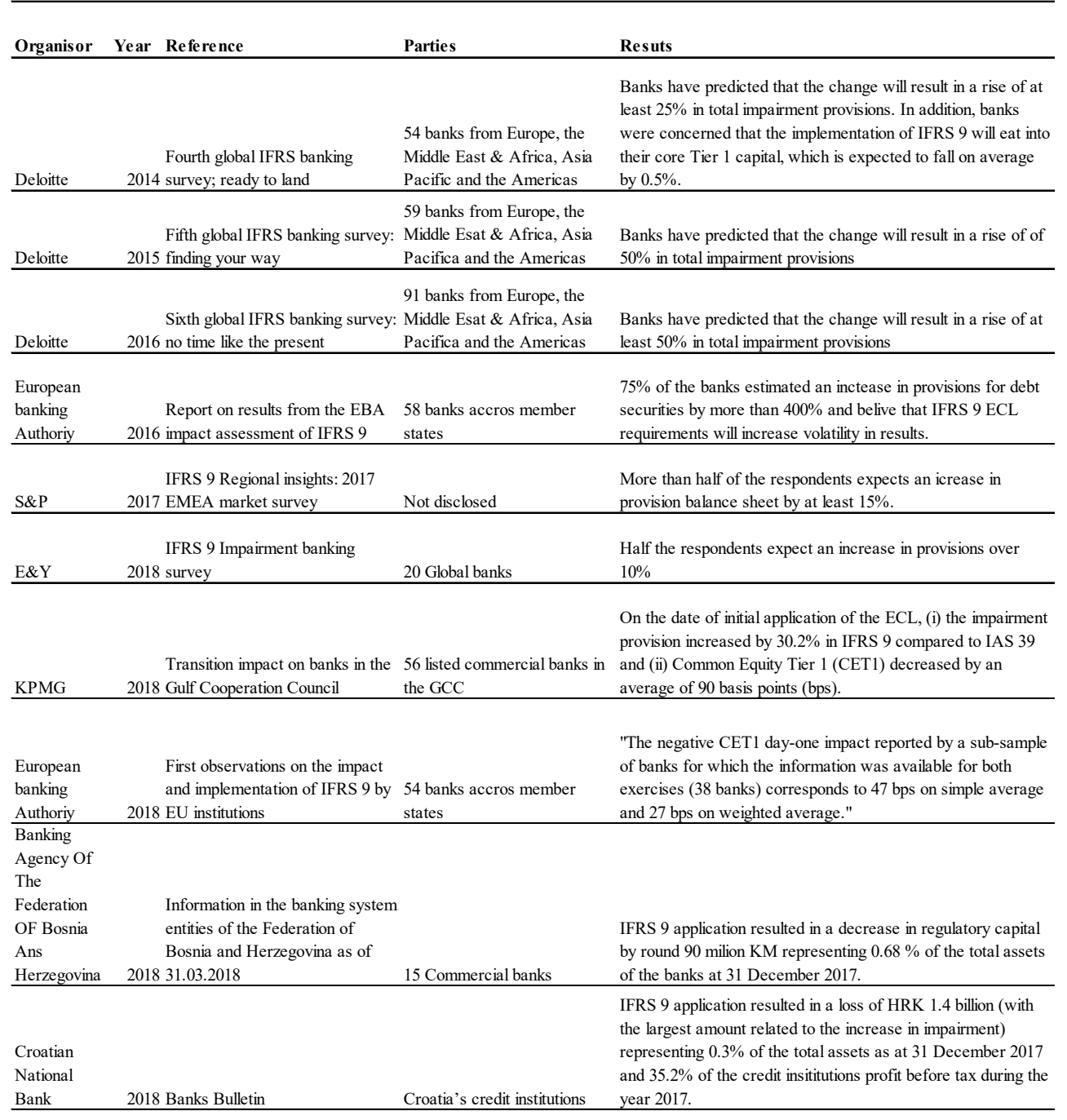

The above table clearly shows that the impact of new ECL requirements is expected to be material to the banks' equity. 


\section{The Lebanese banking sector}

The Lebanese banking industry plays a key role in the Lebanese economy, acting as the main channel for capital inflows into the country and financing the largest part of the government's current account deficit. With around 150\% debt to GDP ratio, Lebanon is the third most indebted country in the world.

The Central Bank of Lebanon plays a vital role in the institutional framework supporting financial stability. It is responsible for protecting the Lebanese Pound, and more specifically for (i) maintaining the economic stability in Lebanon, (ii) safeguarding and regulating the banking industry and (iii) developing the monetary and financial market. Throughout the years, the Central bank policies "helped mitigate risks and maintain confidence. The Central Bank of Lebanon defends the exchange rate, underwrites government debt issuance, keeps interest rates steady at moderate levels, maintains high gross international reserves, provides economic stimulus, and assists in managing weak banks" (World Bank, 2016). More recently, it has been difficult for the Central Bank of Lebanon to maintain the exchange rate between the Lebanese Pound and the US Dollar. The US dollar has been in wide use and circulation over the last 2 decades and against which the Lebanese Pound has been pegged through the period at 1 USD equal to LBP 1507.5. However, during the last quarter of 2019, Lebanon experienced significant shortage in US Dollar and as a result banks in Lebanon implemented an unofficial foreign exchange controls. As a result of the above situation, two other unofficial exchange rates have emerged and applied by (i) foreign exchange brokers and (ii) banks on some type of transactions.

The Banking Control Commission is an administratively independent body of the Central Bank of Lebanon with a mandate to supervise banks and confirm adherence to banking laws and regulations.

Based on the financial sector assessment done by the World Bank (2016), they found that the "regulatory framework is complex in Lebanon, with primary legislation that has not been updated for many years and an extensive set of regulations issued by the Banking Control Commission and the Central Bank of Lebanon". They further suggest that in the medium term, banking legislation could be updated and streamlined.

However, both bodies played a key role in the application of the IFRS 9 in the banking sector. Banks from all sizes in Lebanon early adopted the first version of IFRS 9 issued in 2009, a decision that have been taken by very few banks in the world. The early adoption of the previous version of IFRS 9 together with the issuance of application guidance by the Central Bank of Lebanon and the Banking Control Commission, propose that Lebanese banks are familiar with the requirements of the new standard. Based on a survey conducted by Chedid and 
Chaya (2020) to evaluate the status of IFRS 9 implementation according to internal auditors, the findings suggest an advanced understanding of the IFRS 9 implementation by the respondents.

There are 63 banks operating in Lebanon, of which 13 are subsidiaries of other banks, which reduces the total (when consolidated) to 50. Lebanese banks are classified based on their total deposits:

Table 3. Lebanese banks by category

\begin{tabular}{|c|c|c|c|c|c|}
\hline Numbers in LL million & $\begin{array}{l}\text { Total deposits } \\
\text { range }\end{array}$ & Total assets & $\begin{array}{l}\text { Market share } \\
\text { based on total } \\
\text { assets }\end{array}$ & Total equity & $\begin{array}{l}\text { Market } \\
\text { share based } \\
\text { on equity }\end{array}$ \\
\hline Consolidated Alfa Group & Deposits over LL 3 & $350,964,872$ & $90.30 \%$ & $32,782,377$ & $88.22 \%$ \\
\hline Consolidated Beta Group & Deposits between I & $29,159,331$ & $7.50 \%$ & $2,834,605$ & $7.63 \%$ \\
\hline Consolidated Gamma Group & Deposits between I & $4,809,674$ & $1.24 \%$ & 998,167 & $2.69 \%$ \\
\hline \multirow[t]{2}{*}{ Consolidated Delta Group } & Deposits below LL & $3,723,884$ & $0.96 \%$ & 546,749 & $1.47 \%$ \\
\hline & & $388,657,761$ & $100.00 \%$ & $37,161,898$ & $100.00 \%$ \\
\hline
\end{tabular}

Notes: Source: Authors' creation based on data published in "Bilanbanques 2018 " for 45 banks*.

*: Five banks did not communicate their figures in the Bilanbanques 2018 (These banks are not Alfa banks).

As shown above, banking activity is significantly concentrated in the Alfa Group. The total composition of the banks' assets at 31 December 2017 based on the data published in Bilanbanques 2018 is as follows: Liquid assets $40 \%$; Investment securities 27\%; Loans 29\%; Fixed assets $2 \%$; and Other assets $2 \%$.

The portfolio of investment securities can be broken down as follows: Lebanese Treasury Bills in local currency 26\%; Lebanese Eurobonds 22\%; Central Bank of Lebanon certificate of deposits in local currency 16\%; Central Bank of Lebanon certificate of deposits in foreign currency $25 \%$; Other debt instruments $9 \%$; and Equity instruments $2 \%$. The portfolio of liquid assets can be detailed as follows: Accounts with Central Banks 80\%; and Accounts with banks 20\%.

The asset composition reveals the huge exposure of Lebanese banks to sovereign risk, with more than $55 \%$ of the assets composed of government and central bank paper and current accounts as follows:

- Investments with the Lebanese government and the Central Bank of Lebanon constitute $90 \%$ of the investment securities portfolio

- The Central Banks hold $80 \%$ of the liquid assets related to cash and placement

Although Lebanon's debt burden remains among the highest in the world (debt to GDP and to revenue ratios), up till 31 December 2019, the country had never defaulted on its dues, even during periods of economic crisis and civil war.

From the IFRS 9 perspective, Lebanese banks should book an ECL on loans, investment securities, and liquid assets on 1 January 2018. Under the incurred loss 
model, no provisions have been booked for $90 \%$ of investment securities and $80 \%$ of liquid assets (as no default has occurred on Lebanese sovereign exposure). Accordingly, the introduction of the new ECL requirements will lead to an increase in provision on the portfolio of investment securities and liquid assets.

As for the loan portfolio, under IAS 39, a specific and collective provision has been booked by Lebanese banks as follows:

Figure 2. Provision ratio 2013 until 2017

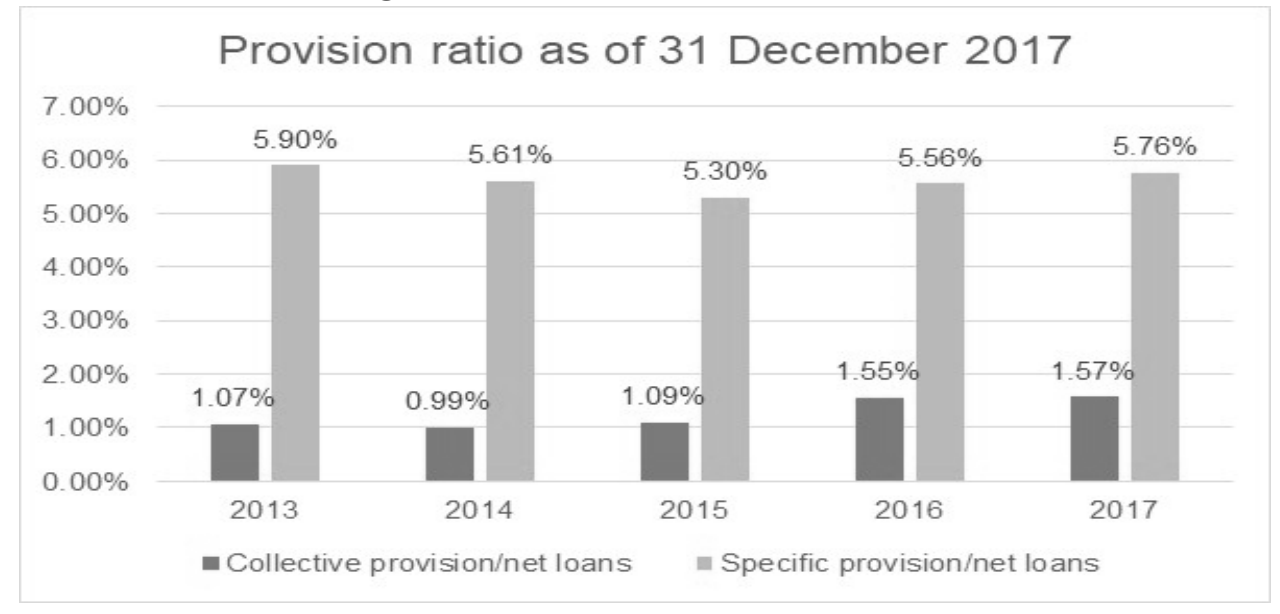

In the next section, we develop our hypotheses based on the information presented in the previous pages.

\section{Hypotheses development}

Based on the preceding paragraphs, we formulate the following hypotheses. Consistent with the findings of the European Banking Commission (2018), KPMG (2018), Sultanoğlu (2018), Abad and Suarez (2017), Csaba (2017) and other surveys as shown in Table 2, we expect a material impact of the new expected loss requirements of IFRS 9 (2014) on the bank's equity. The materiality threshold is defined for the purpose of our study at $1 \%$ of the bank's equity.

H1. The impact of the new Expected Credit Loss requirements of IFRS 9 (2014) is material to the Lebanese banks' accounts.

The calculation of ECL must reflect information about historical events and current circumstances in addition to reasonable and supportable forecasts of expected future events and economic situations. Historical and current credit losses are indicators of a bank risk appetite, investment and lending strategy and, ultimately, expected credit loss. 
As explained in the previous section, the asset composition of the banks' balance sheet reveals the huge exposure of Lebanese banks to sovereign risk, with more than $55 \%$ of the assets composed of government and central bank paper and current accounts. Under the incurred loss model, no provisions have been booked for all these amounts as no default occurred up till 1 January 2018. Accordingly, the introduction of the new ECL requirements will lead to a one-day loss (increase in provision) on the portfolio of investment securities and liquid assets at 1 January 2018.

For loans and advances, banks have built up their specific and collective provisions under IAS 39. As the calculation of ECL must reflect information about historical events and current events, the new ECL should be directly related to the level of provisioning booked in the past few years and the current provision booked.

On that basis, we hypothesize that the new ECL is positively associated with the average credit losses for the last five years, the current provisions level for loans and advances to clients, and the size of the bank's remaining major financial assets subject to IFRS 9 (percentage of the investment securities and percentage of the liquid assets).

H2. The IFRS 9 new ECL is positively associated with the extent average annual credit losses for the past five years.

H3. The IFRS 9 new ECL is positively associated with the extent of current provisions levels for loans.

H4. The IFRS 9 new ECL is positively associated with the size of the portfolio of investments securities.

H5. The IFRS 9 new ECL is positively associated with the size of the portfolio of liquid assets.

In the next section, we present the research methodology, including sample selection and measurement of variables.

\section{Research Methodology}

This study involves an analysis of Lebanese banks for the financial year ending on 31 December 2017. To test our hypotheses, we used two primary strategies: (i) calculating statistical figures based on available information for the first H1, and (ii) establishing a multiple regression model which regresses the increase in provision due to the ECL on a set of variables (average historical credit losses, current provisions level for the loans portfolio, portfolio of investment securities, and portfolio of liquid assets) for $\mathrm{H} 2, \mathrm{H} 3, \mathrm{H} 4$, and $\mathrm{H} 5$. Based on the results of the 
regression model, we included additional testing and refined the model by removing non-significant independent variables.

\subsection{Sample selection}

To address our research questions, we hand-collected financial and nonfinancial data of Lebanese banks for the year 2017 from two sources: (1) the audited financial statements of the banks published on their website: (2) Bilanbanques 2018 published by Bankdata Financial services in collaboration with the Association of Banks in Lebanon.

As mentioned previously, there are 63 banks operating in Lebanon, of which 13 are subsidiaries of other banks. This brings the total number of banks (when consolidated) to 50 .

Of the 45 consolidated banks in Bilanbanques 2017, we excluded the banks (21) that did not publish their audited financial statements on their website. These were 7 Beta banks, 1 Gamma bank and 13 Delta banks. Then we excluded the banks (2) that did not disclose the impact of IFRS 9 in their audited financial statements - one Alfa bank and one Gamma bank.

Therefore, our sample included 22 banks:

Table 4. Sample coverage

\begin{tabular}{|c|c|c|c|c|}
\hline & $\begin{array}{l}\text { Number of bank } \\
\text { Groups in our } \\
\text { sample }\end{array}$ & $\begin{array}{l}\text { Number of banks } \\
\text { on separate basis } \\
\text { (non-consolidated) }\end{array}$ & Total assets & Total equity \\
\hline & Number & Number & LL Million & LL Million \\
\hline Consolidated Alfa Group & 13 & 14 & $341,384,355$ & $31,811,891$ \\
\hline Consolidated Beta Group & 5 & 7 & $13,677,105$ & $1,221,696$ \\
\hline Consolidated Gamma Group & 1 & 4 & $1,588,346$ & 315,855 \\
\hline Consolidated Delta Group & 3 & 10 & $2,600,236$ & 678,495 \\
\hline Total of our sample & 22 & 35 & $359,250,042$ & $\mathbf{3 4 , 0 2 7 , 9 3 7}$ \\
\hline Total as per Bilanbanques 2018 & 45 & 58 & $388,657,761$ & $37,161,898$ \\
\hline Percetange covered & $48.89 \%$ & $60.34 \%$ & $92.43 \%$ & $91.57 \%$ \\
\hline
\end{tabular}

As we can see from Table 4, our sample covered $92 \%$ of the total assets and equity of Lebanese banks, which helped us draw conclusions for the whole banking sector due to the vast coverage we were able to achieve. 


\subsection{Measurement of the variables}

We briefly present the variables used to test the hypotheses.

Our dependent variable $(\Delta \mathrm{P})$ is the increase in provision because of the new ECL model.

$\Delta \mathbf{P}=\underline{\text { Increase in provision based on new ECL }}$

Total provisions as of 31 December 2017

The increase in provision was collected from the section related to the standards issued but not yet effective in the notes to the audited financial statements.

We used independent variables to regress with the dependent variable, i.e. increase in provision. The variables were: 1) average yearly historical credit loss from 2013 until 2017 (AVHCL); 2) current provision level for loans under the incurred loss model as of 31 December 2017 (ILL); 3) the investment securities portfolio as of 31 December 2017 (IS); and 4) the liquid assets portfolio (LA) as of 31 December 2017. To control for the bank size, we divided all variables, except ILL, by the bank's total assets. Accordingly, our variables are as follow:

Average yearly historical credit loss from 2013 until 2017:

AVHCL $=\quad$ Yearly Average (credit loss from 2013 until 2017)

Average total assets from 2013 until 2017

The yearly credit loss and total assets were taken from Bilanbanques 2014 to 2018, which includes the banks' balance sheet and income statements from 2013 until 2017.

1) Current provision level for loans under the incurred loss model as of 31 December 2017:

ILL $=\sum$ Specific and collective provisions for loan portfolio as of 31 December 2017 Gross loan portfolio as of 31 December 2017

Specific and collective provisions were extracted from the notes to the banks' financial statements, and the gross loan portfolio was extracted from Bilanbanques 2018.

2) Investment securities portfolio as of 31 December 2017:

$\mathbf{I S}=\quad$ Portfolio of investment securities as of 31 December 2017

Total assets as of 31 Dec 2017 
The percentage of the investment securities portfolio was obtained from Bilanbanques as disclosed under the breakdown of the assets graph.

3) Liquid assets portfolio as of 31 December 2017:

$\mathbf{L A}=\underline{\text { Cash and balances with central banks }+ \text { deposits with banks as of } 31 \text { Dec } 2017}$ Total assets as of 31 Dec 2017

The percentage of the liquid assets portfolio was obtained from Bilanbanques as disclosed under the breakdown of assets graph.

The data was collected manually. Adjustment to some figures reported was necessary as explained in the next paragraph.

Adjustment to amounts reported in the audited financial statements and Bilanbanques:

In 2016, the Central Bank of Lebanon engaged in swap transactions with local banks, whereby it offered those banks the option of discounting long dated Lebanese Pound treasury bills on the condition that the banks purchase foreign currency denominated Lebanese sovereign bonds or certificates of deposit from the Central Bank in an amount equivalent to the nominal value of the discounted treasury bills and on highly preferential terms. Consequently, there were approximately USD 14 billion of exchange transactions across the Lebanese banking system, generating significant non-recurrent revenues to Lebanese banks. Later during the same year, the Central Bank issued intermediary circular no. 446, which set out proper use and accounting for exceptional revenues resulting from swap transactions, including allocating extra collective provisions equal to $2 \%$ of risk weighted loans and additional forecasted provisions for the IFRS 9 new ECL model. The implementation of the circular resulted in non-recurrent expenses and income in the banks' income statements, in addition to dissimilarity in accounting for swap transactions between different banks. For example, some banks reported the whole income as deferred income conditional to the IFRS 9 implementation as of 1 January 2018, whereas other banks reported the full income and provided for the $2 \%$ provision required by the circular. Moreover, divergence was noted between external auditors' treatment of the same transaction. This resulted in several external auditors qualifying their opinion on the banks' financial statements for the year 2016 and 2017, due to excess provisions not compliant with IAS 39.

Accordingly, and to properly assess the impact of IFRS 9, we have adjusted the historical and actual credit losses included in the computation of the above variables $(\triangle \mathrm{P}, \mathrm{AVHCL}, \mathrm{ILL})$ to incorporate the following: 
- $\quad$ Eliminated the additional provisions required by the Central Bank (2\% of risk weighted loans); and

- Eliminated the overprovision booked by the banks that external auditors qualified their opinion on.

All tested variables are summarized in the research model below:

Figure 3. Research model; dependent and independent variables

\section{Independent variables}

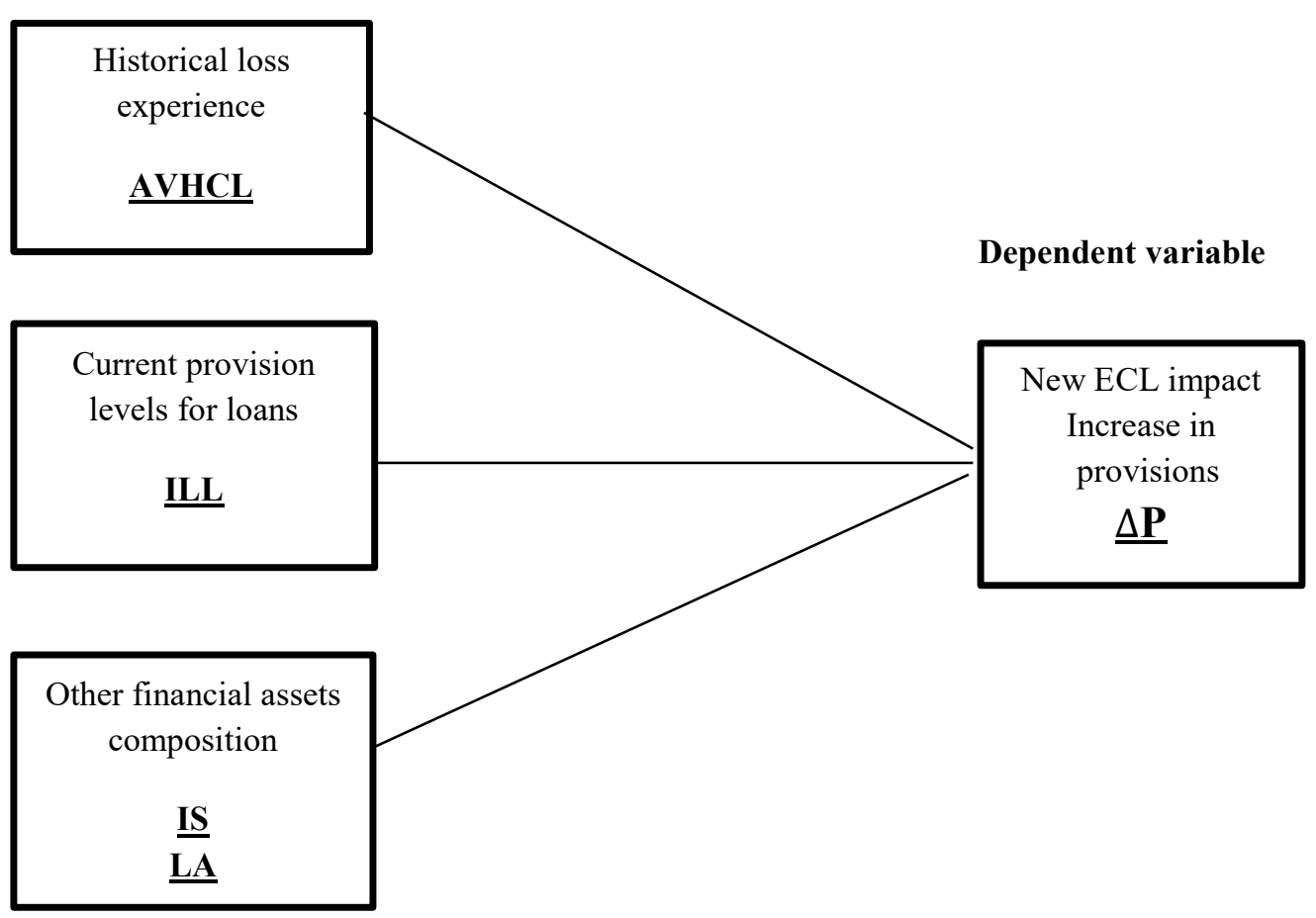

The following regression equation is assumed to test the hypotheses $\mathrm{H} 2$ to $\mathrm{H} 5$.

$\Delta P_{(i)}=c+\beta_{1} A V H C L_{(i)}+\beta_{2} I L L_{(i)}+\beta_{3} I S_{(i)}+\beta_{4} L A_{(i)}+v i_{(t)}$

Multiple regression analysis was performed between the ECL impact $(\Delta \mathrm{P})$ as the dependent variable and all four variables as indicated above.

To test the first hypothesis (H1), we calculated two ratios:

$\underline{\Delta \mathbf{P}}$ : which calculates the impact of ECL as a percentage of equity; and Equity

$\underline{\text { Adjusted } \Delta \mathbf{P}}$ : which calculates the impact of ECL as a percentage of equity, taking 
Equity into account in the numerator the amount that will be credited to the banks' equity only.

The above two ratios will be different when banks have booked the following amounts as preparation for IFRS 9:

1- Excess provisions for which auditors qualified their opinion;

2- Regulatory $2 \%$ exceeding provision;

3- Swap gain previously discussed under regulatory provisions that will be allocated directly to IFRS 9 with no impact on equity.

Adjusted $\Delta \mathbf{P}=\Delta \mathrm{P}$ - Excess (Balance sheet provisions \& deferred regulatory provisions).

The materiality is set at $1 \%$ of the bank's total equity.

The results of our study are detailed below.

\section{Results}

\subsection{Descriptive statistics}

First, we present the descriptive statistics for the variables in the regression model. Table 5 reports the means, standard deviation, median, range, etc. of each variable for the entire sample.

Table 5. Descriptive statistics of dependent and independent variables

\begin{tabular}{lccccc}
\hline & $\Delta \boldsymbol{P}$ & $\boldsymbol{A} \boldsymbol{V H} \boldsymbol{C} \boldsymbol{L}$ & $\boldsymbol{I L} \boldsymbol{L}$ & $\boldsymbol{I S}$ & $\boldsymbol{L} \boldsymbol{A}$ \\
\hline & & & & & \\
Mean & 0.4336 & 0.0012 & 0.0999 & 0.2877 & 0.3859 \\
Standard Error & 0.1275 & 0.0003 & 0.0421 & 0.0197 & 0.0220 \\
Median & 0.2682 & 0.0010 & 0.0522 & 0.3050 & 0.3550 \\
Standard De viation & 0.5979 & 0.0012 & 0.1975 & 0.0925 & 0.1031 \\
Sample Variance & 0.3575 & 0.0000 & 0.0390 & 0.0086 & 0.0106 \\
Kurtosis & 14.1910 & 4.3053 & 19.7031 & 0.1947 & $(0.5980)$ \\
Skewness & 3.4970 & 1.5803 & 4.3557 & $(0.6195)$ & 0.5638 \\
Range & 2.8557 & 0.0061 & 0.9493 & 0.3700 & 0.3600 \\
Minimum & 0.0179 & $(0.0009)$ & 0.0141 & 0.0600 & 0.2300 \\
Maximum & 2.8735 & 0.0052 & 0.9634 & 0.4300 & 0.5900 \\
Sum & 9.5396 & 0.0269 & 2.1971 & 6.3300 & 8.4900 \\
Count & 22 & 22 & 22 & 22 & 22 \\
\hline
\end{tabular}


The table above indicates that, in their financial statements, banks reported that the average increase in provisions as a result of the new ECL is around $43 \%$ of their current provisions. The average annual historical credit loss is around $0.12 \%$ of the total assets. On average, banks have $10 \%$ provisions on their gross loan portfolios. The portfolios of investment securities constitute around 39\% of the banks' total assets. While analyzing the data gathered, we observed that two banks had a negative AVHCL (release of provision rather than provision for credit loss under incurred loss model). Moreover, one had a very high ILL level of $96 \%$, compared to a mean of $10 \%$ as shown in the table above. In addition, we noticed that, for a third bank, the dependent variable was very high compared to the average of the sample $(287 \%$ compared to a mean of $43 \%$ ) representing an outlier. When further studying the accounts of these three banks, we decided to remove them from the population as they are three small banks ( 2 Gamma and 1 Delta) that represent special cases (new banks or banks with very small or special lending activities).

Our new sample coverage is presented as follows:

Table 6. Final sample covered

\begin{tabular}{|c|c|c|c|c|}
\hline & $\begin{array}{l}\text { Number of bank } \\
\text { Groups in our } \\
\text { sample } \\
\end{array}$ & $\begin{array}{l}\text { Number of banks } \\
\text { on separate basis } \\
\text { (non-consolidated) }\end{array}$ & Total assets & Total equity \\
\hline & Number & Number & LL Million & LL Million \\
\hline Consolidated Alfa Group & 13 & 14 & $341,384,355$ & $31,811,891$ \\
\hline Consolidated Beta Group & 5 & 7 & $13,677,105$ & $1,221,696$ \\
\hline Consolidated Gamma Group & - & 2 & - & - \\
\hline Consolidated Delta Group & 1 & 8 & 191,012 & 64,093 \\
\hline Total of our sample & 19 & 31 & $355,252,472$ & $33,097,680$ \\
\hline Total as per Bilanbanques 2018 & 45 & 58 & $388,657,761$ & $37,161,898$ \\
\hline Percetange covered & $42.22 \%$ & $53.45 \%$ & $91.40 \%$ & $89.06 \%$ \\
\hline
\end{tabular}

We observed that although the number of bank groups covered decreased by $14 \%$ (from 22 groups to 19 groups), the total consolidated assets was still mostly unchanged (from a coverage of $92 \%$ to a coverage of $91 \%$ ), whereas total equity decreased slightly from a coverage of $91.57 \%$ to $89.06 \%$. However, the coverage achieved in the adjusted sample is still high and considered important to help us draw conclusions for the whole banking sector.

Table 7 includes correlations between the different variables in the regression model based on the adjusted sample. 
Table 7. Coefficient of correlation between dependent and independent variables.

\begin{tabular}{lccccc}
\hline Correlation & $\Delta \mathbf{P}$ & AVHCL & ILL & IS & LA \\
\hline$\Delta \mathbf{P}$ & 1.0000 & & & & \\
AVHCL & $(0.5054)$ & 1.0000 & & & \\
ILL & $(0.3144)$ & 0.3395 & 1.0000 & & \\
IS & 0.3488 & 0.0606 & 0.3039 & 1.0000 & \\
LA & $(0.0185)$ & $(0.1686)$ & 0.0178 & $(0.3890)$ & 1.0000 \\
\hline
\end{tabular}

The highest correlation of the dependent and independent variables is between the increase in provisions and the average credit loss ratio, with a negative coefficient of 0.50 . The highest correlation for the independent variables is between the investment securities portfolio and the liquid assets portfolio (which is expected, as theoretically the sizes should move in opposite way) with a negative coefficient of 0.40 . Accordingly, multicollinearity is not presently an issue.

After presenting the descriptive statistics, we present the result of data analysis for ECL.

\subsection{ECL and results of the multiple regression model}

Table 8 summarizes the regression results of the estimates of the increase in provision for Lebanese banks. We present the following equation:

$$
\Delta P_{(i)}=0.0011-84.1688 A V H C L_{(i)}-3.0330 I L L_{(i)}+1.7518 I S i_{(i)}+0.3216 L A_{(i)}
$$

Table 8. Results of multiple regression analysis

\begin{tabular}{lccl}
\hline Variables & Coefficient & P-value & \\
\hline C & $(0.0011)$ & 0.9975 & \\
AVHCL & $(84.1688)$ & 0.0751 & $* *$ \\
ILL & $(3.0330)$ & 0.1418 & \\
IS & 1.7518 & 0.0332 & $*$ \\
LA & 0.3216 & 0.5735 & \\
\hline
\end{tabular}

\begin{tabular}{lr}
\hline Model res ults : & \\
R Square & 0.4902 \\
Adjusted R Square & 0.3445 \\
Standard Error & 0.2024 \\
Observations & 19.0000 \\
Significance F & 0.0397
\end{tabular}

Notes: The asterisks ** and $*$ indicate significance at the $7.5 \%$ and $5 \%$ levels, respectively. 
The adjusted R-squared is $34 \%$, meaning that $34 \%$ of the increase in the provision can be explained by the independent variables. The t-statistics of AVHCL and IS are significant at $7.5 \%$ and $5 \%$ respectively. We do not find an association between the increase of provision, the liquid assets portfolios, and the current provision for loans. Although LA coefficient is positive as predicted, it is not statistically significant and, therefore, we do not find support for $\mathrm{H} 3$ or H5. In addition, the constant $\mathrm{C}$ is not statistically significant to the model. As for $\mathrm{H} 2$, we partially reject the hypothesis, since we were able to establish that the IFRS 9 new ECL is negatively associated with the extent of average annual credit losses for the past five years.

In order to refine the study, and based on the above results, we eliminated the constant and non-significant independent variables (LA and ILL) and established the following new equation:

$$
\Delta P_{(i)}=\alpha_{1} A V H C L_{(i)}+\alpha_{2} I S i_{(i)}+v i_{(t)}
$$

Table 9 summarizes the regression results of the estimates of the new equation.

$$
\Delta P_{(i)}=-104.4533 A \mathrm{VHCL}_{(i)}+1.6809 I S i_{(i)}
$$

Table 9. Results of adjusted multiple regression analysis

\begin{tabular}{lcc}
\hline Variables & Coefficient & P-value \\
\hline AVHCL & $(104.4533)$ & $0.0158 * *$ \\
IS & 1.6809 & $0.0000 *$ \\
\hline Model res ults : & & \\
R Square & 0.7940 & \\
Adjusted R Square & 0.7231 & \\
Standard Error & 0.2021 & \\
Observations & 19.0000 & \\
Significance F & 0.0000 & \\
\hline Notes : The asterisks ** and * indicate significance at the $2 \%$ \\
and 1\% levels, respectively. \\
\hline
\end{tabular}

The results of the new multiple regression model are more robust (adjusted Rsquared $=72 \%$ and Significance $F=0$ ) and generally consistent with the results of the first equation and the coefficient of correlation. The findings suggest that the new ECL is significantly negatively related/correlated to AVHCL (rejecting H2) and significantly positively correlated to IS (confirming H4).

In brief, we reject $\mathrm{H} 2, \mathrm{H} 3$, and $\mathrm{H} 5$ and accept $\mathrm{H} 4$.

To test our first hypothesis ( $\mathrm{H} 1$ ), we calculated the ratio of $\Delta \mathrm{P} /$ Equity and Adjusted $\Delta \mathrm{P} /$ Equity for the 19 banks and obtained the following results: 
Table 10. Descriptive statistics for the ECL impact on Equity

\begin{tabular}{lcc}
\hline & $\Delta$ P/Equity & Adjusted $\Delta$ P/Equity \\
\hline Mean & 0.0542 & 0.0087 \\
Standard Error & 0.0095 & 0.0047 \\
Median & 0.0383 & - \\
Standard Deviation & 0.0413 & 0.0206 \\
Sample Variance & 0.0017 & 0.0004 \\
Kurtosis & $0.7349)$ & 8.3324 \\
Skewness & 0.7117 & 2.8226 \\
Range & 0.1256 & 0.0806 \\
Minimum & 0.0053 & - \\
Maximum & 0.1309 & 0.0806 \\
Sum & 1.0306 & 0.1659 \\
Count & 19 & 19 \\
\hline
\end{tabular}

\begin{tabular}{lll}
\hline Weighted ave rage ratio & 0.0389 & 0.0034 \\
\hline
\end{tabular}

The table above implies that the ECL weighted average impact on the banks' equity is around $3.89 \%$, with a minimum of $0.5 \%$ and a maximum of $13 \%$. However, since many banks had excess and regulatory provisions booked in anticipation of IFRS 9, the real impact of the ECL was around $0.34 \%$ of the equity. This indicates that, on average, the new ECL model will lead to a decrease in equity by around $0.35 \%$ for Lebanese banks. Based on that, we conclude that the new ECL model has a theoretically significant impact on the banks' equity; however, since some banks had excess provisions booked during 2016 and 2017, the actual impact was not material. Accordingly, we reject $\mathrm{H} 1$.

\subsection{Verification of findings}

We decided further to confirm whether the findings can be generalized and the equation found can be applied to banks in other countries. For that purpose, we selected all Jordanian banks listed on Amman Stock exchange and applying the International Financial Reporting Standards (sample of 13 Jordanian banks) and verified whether the results are similar.

Jordan's government debt represents around to 92\% of the country's GDP in 2019 and Jordanian banks have high exposure to domestic sovereign debt, similarly to the Lebanese banks, although much lower.

We hand-collected financial and nonfinancial data of Jordanian banks for the years 2013 to 2018 from the audited financial statements published on Amman Stock Exchange website. The actual ECL impact recognized on 1 January 2018 was used instead of the disclosure in the 2017 financial statements. 
Table 11. Descriptive statistics for the variables $\triangle P, A V H C L$ and IS

\begin{tabular}{lccc}
\hline & $\Delta \mathbf{P}$ & IS & AVHCL \\
\hline & & & \\
Mean & 0.4861 & 0.2170 & 0.0175 \\
Standard Error & 0.1043 & 0.0197 & 0.0030 \\
Median & 0.3663 & 0.2100 & 0.0191 \\
Standard Deviation & 0.3761 & 0.0709 & 0.0109 \\
Sample Variance & 0.1414 & 0.0050 & 0.0001 \\
Kurtosis & $(0.0831)$ & $(0.7032)$ & $(1.2650)$ \\
Skewness & 1.1912 & 0.5489 & 0.0669 \\
Range & 1.0512 & 0.2105 & 0.0320 \\
Minimum & 0.1348 & 0.1304 & 0.0016 \\
Maximum & 1.1860 & 0.3409 & 0.0336 \\
Sum & 6.3197 & 2.8214 & 0.2269 \\
Count & 13 & 13 & 13 \\
\hline
\end{tabular}

The table above indicates that banks reported that the average increase in provisions as a result of the new ECL is around $49 \%$ (43\% for Lebanese banks) of their current provisions. The average annual historical credit loss is around $1.75 \%(0.12 \%$ for Lebanese banks) of the total assets. The portfolios of investment securities constitute around $22 \%$ of the banks' total assets (39\% of Lebanese banks).

Table 12 summarizes the regression results of the estimates of the increase in provision for Lebanese banks.

Table 12. Results of adjusted multiple regression analysis

\begin{tabular}{lrr}
\hline Variables & Coefficient & P-value \\
\hline IS & 1.6538 & $0.0305 *$ \\
AVHCL & 8.2406 & 0.2925 \\
\hline Model results: & \\
R Square & 0.8547 \\
Adjusted R Square & 0.6151 \\
Standard Error & 0.3418 \\
Observations & 13.0000 \\
Significance F & 0.0010 \\
\hline Notes: The asterisk * indicates significance at the 5\% \\
level.
\end{tabular}

The results of the regression model (adjusted R-squared $=62 \%$ and Significance $\mathrm{F}=0.001$ ) suggest that the new ECL is not significantly related AVHCL (knowing 
that the coefficient is positive in the case of Jordanian banks while negative for Lebanese banks) and significantly positively correlated to IS (similar to Lebanese banks).

The model result confirm that the new ECL is significantly positively correlated to the investment securities portfolio as of date of application.

\subsection{Further analysis on 2018 ECL}

According to previous studies, most researchers found that management use its discretionary power on loan loss provision to smooth earnings (Greenawalt \& Sinkey, 1988, Lobo \& Yang, 2001, Fonseca \& Gonzalez, 2008, Bushman \& Williams, 2012, Kilic et al., 2013). To explore further these findings in the Lebanese and IFRS 9 context, we tested Casta el al (2019) hypothesis that banks "decrease (increase) their level of loan loss provisions when day-one losses reported in retained earnings are higher (lower)". For that purpose, we calculated the coefficient of correlation between $\triangle P$ and ECL 2018.

ECL 2018 $=\quad$ ECL recognized in the income statement in 2018 Total assets as of 31 December 2018

The information for ECL 2018 was hand-collected for Lebanese banks for the year ended 2018 from Bilanbanques 2018 published by Bankdata Financial services in collaboration with the Association of Banks in Lebanon.

Table 13. Descriptive statistics for the ECL 2018

ECL 2018

\begin{tabular}{lc} 
Mean & 0.1830 \\
Standard Error & 0.1024 \\
Median & 0.0376 \\
Standard Deviation & 0.4463 \\
Sample Variance & 0.1992 \\
Kurtosis & 16.5121 \\
Skewness & 3.9681 \\
Range & 2.0060 \\
Minimum & $(0.0333)$ \\
Maximum & 1.9727 \\
Sum & 3.4770 \\
Count & 19 \\
\hline
\end{tabular}


The coefficient of correlation between $\Delta \mathrm{P}$ and ECL 2018 is determined at 0.375 implying a moderate positive linear relationship between the two variables. The results do not support the hypothesis that Lebanese banks use their discretionary power on loan loss provision to smooth earnings by decreasing their loan loss provision when the impact of IFRS 9 adoption on retained earnings is higher.

\section{Discussion and analysis}

Based on a sample of 19 banks representing $92 \%$ and $89 \%$ of the total consolidated balance sheets and shareholders' equities of all Lebanese banks respectively, we found that the real impact of the new requirements of the ECL model is not material to the banks' equities and, accordingly, we will not detect a material decrease in the opening retained earnings of the banks equity in the financial statements of 2018 (as of 1 January 2018). Accordingly, H1 was rejected; the impact of the new ECL requirements of IFRS 9 (2014) is found not to be material to the Lebanese banks' accounts when compared to their equity. This is somewhat consistent with the Deloitte survey in 2016, in which banks expressed concerns that the implementation of IFRS 9 will eat into their core Tier 1 capital, which was expected to fall by $0.5 \%$ on average. The probable reason is that most Lebanese banks have built specific and collective provisions under the prudent requirements of the Central Bank of Lebanon over the last few years, which helped decrease the impact of the potential IFRS 9 ECL model on the banks' equities upon implementation. In fact, the Central Bank of Lebanon and the Banking Control Commission have historically requested banks to book conservative provisions by (i) setting minimum requirements for collective provisions on performing retail portfolio (i.e. where late settlements do not exceed 30 days) calculated at $2 \%$ of the portfolio by 31 December 2017 as per circular no. 280 (BCCL, 2015); (ii) asking banks to apply a preset conservative provision matrix for past-due retail and housing loans as per circular No.280 (BCCL, 2015); and (iii) applying high haircuts $(40 \%)$ on real estate guarantees when computing specific provisions.

The findings are somehow consistent with Sultanoğlu (2018) suggestions that Turkish banks will face reverse impacts when adopting IFRS 9 for the first time as a result of the previous application of specified rate for calculating general and specific provision as required by the Turkish regulator. In addition, the findings are aligned with Seitz et al. (2018) suggestion that the new ECL provisions are not generally higher in a normal business time.

The results of our multiple regression model are extremely valuable. With an adjusted R-squared of $72 \%$, the results show that $72 \%$ of the increase in provisions can be explained by the independent variables, average historical credit loss for five years, and portfolio of investment securities. Although the findings do not support $\mathrm{H} 2$ as the relationship identified was negative for AVHCL, the results are extremely useful from a statistical perspective. The negative relationship between the historical 
credit loss ratio and the IFRS 9 ECL impact supports the statement in the previous paragraph, confirming that when banks had built large historical provisions throughout the previous five years, the ECL impact was lower. These banks had probably overprovided for collective and specific provisions as mentioned above, in compliance with thresholds set by the regulator. Stated differently, the higher the level of provisioning in previous years, the lower the impact of ECL due to adequate and conservative provisioning prior to the IFRS 9 implementation. In fact, figure 2 demonstrates clearly how the average collective provision increased in banks during 2016 and 2017.

The significant positive relationship between the increase in provision and the portfolio of investment securities is consistent with $\mathrm{H} 4$, reflecting the increase in provision levels on a portfolio where almost $90 \%$ of its size has never been provided for. The reason for this is that around $90 \%$ of this portfolio comprises sovereign bonds that have never defaulted and accordingly had zero historical credit loss. Under IFRS 9, a provision should now be booked based on the sovereign risk, and this provision is directly linked to the size of this portfolio. The findings are consistent with the understanding of IFRS 9 where the ECL requirements brings more impairment loss burden to the banks as a result of the ECL on financial assets classified in Stage 1 and 2

In addition, the findings do not support $\mathrm{H} 3$ concerning a significant positive association between the current provision level loans and the ECL impact. The "negative association" can be explained as for AVHCL. A significant relationship $(\mathrm{p}=14 \%)$ is not identified because the ILL ratio is highly impacted by the banks' write-off policies. The ratio has been computed as the sum of the collective and specific provisions divided by the total gross loans. Total gross loans included normal and impaired loans. Where different banks apply different write-off policies (different periods before moving the client to off balance sheet accounts), this may lead to a huge variation in the quality of information provided by this ratio. Two of the three banks removed from the sample had high ILL, reaching $20 \%$ and $96 \%$ compared to an average of $10 \%$. This indicates that, in practice, there is a difference in the write-off policy between banks, which may be the reason for not finding a significant relationship with our dependent variable.

The findings also do not support H5 concerning a significant positive association between the increase in provisions and the portfolio of liquid assets. The nonassociation outcomes can be explained by the fact that although, theoretically, liquid assets are in the scope of IFRS 9 impairment and are subject to the full 3-stage model, it is unlikely there would be a material impairment charge as most of these liquid assets are short term in nature. IFRS 9 notes that the "maximum period to consider when measuring ECL is the maximum contractual period over which the entity is exposed to credit risk" (IFRS Foundation, 2014). If we take the example of bank accounts on demand, the maximum contractual period is the period needed to 
transfer the cash once demanded, which is typically one day or less. Accordingly, the ECL computation is based on the assumption that the current account is demanded at the balance sheet date and would reflect the losses arising from the oneday credit risk exposure, which, theoretically, should not be material. The results are consistent with Ernst \& Young's expectations that entities with "shorter term assets are likely to be less significantly affected" (Ernst \& Young 2018).

Our findings suggest that:

- Although liquid assets are subject to the new ECL requirements, their size is not positively associated to the new ECL as of date of IFRS 9 adoption;

- Portfolios of financial assets that have not been credit impaired under IAS 39, are positively associated with the new ECL as of date of IFRS 9 adoption; and

- In countries where regulators previously imposed minimum conservative requirements for provisions on loans and advances to clients, the new ECL as of date of adoption is not theoretically higher than the previous provision prior to IFRS 9 implementation.

Additional analysis was done to confirm whether the findings of $\mathrm{H} 2$ and $\mathrm{H} 4$ can be generalized in another country. Based on a sample of Jordanian banks, we confirmed that the ECL is significantly positively related to the investment securities portfolio (confirming H4 in the Jordanian context) as of date of application. The analysis did not reveal an association between the new ECL and the average historical credit loss for five years (rejecting H2). As mentioned above, the results of the AVHCL in the Lebanese context are mainly driven by the local regulators requirements to accumulate provision previously which is not the case for Jordanian banks.

In addition, further analysis was performed to confirm whether Lebanese banks might use their discretionary power on loan loss provision to smooth earnings by decreasing/increasing their loan loss provision in 2018 when the impact of IFRS 9 adoption on retained earnings is higher/lower. Our results did not confirm the income smoothing hypothesis.

\section{Conclusion}

The results presented in this paper provide preliminary evidence on the impact of IFRS 9 adoption for a large sample of Lebanese banks representing $91 \%$ of the total consolidated Lebanese banks' assets.

The work concluded that the impact of the new ECL provision is not material to the Lebanese banks equity (materiality has been determined at $1 \%$ of total equity). Consequently, we can conclude that banks in Lebanon are not expected to witness a material decrease in their equity as a result of the first-time adoption of IFRS 9 on 1 January 2018. Most importantly, we found that the increase in provision based on 
the ECL model is strongly positively related to the portfolio of investments securities and negatively related to the historical credit loss ratio.

However, the results presented here constitute some early evidence about IFRS 9 adoption. The results of our study are subject to several limitations, suggesting the necessity for further research:

- The focus of this study is only on the equity impact as of date of adoption; however, future studies should focus on the impact on the result of the period.

- The empirical literature regarding the IFRS 9 is nascent due to its recent implementation in 2018. More specifically, the impact of IFRS 9 application at the date of adoption, which is the subject of our study, has been dealt with limitedly.

- The sample covered in this paper includes mainly the largest bank in Lebanon (Alfa banks). Therefore, the findings may not be generalizable to other smaller banks.

- The variables used in the model are mainly computed based on historical data. Future research should focus more on including forward-looking information (macroeconomic factors).

- The study relies on the amounts disclosed by the banks in their audited financial statements for 2017. These amounts are disclosed as per IAS 8 and represent known or reasonably estimable information at the date of disclosure. Therefore, the amounts disclosed are preliminary and might be subject to changes. Final figures can be analyzed again once the audited financial statements of 2018 are issued.

- Manual adjustments were made on the amounts reported in the financial statements to account for excess provisions and regulatory provisions booked previously in anticipation of IFRS 9 implementation. These adjustments are as robust and accurate as the quality and clarity of disclosures in the financial statements and the audit opinions where applicable.

Most of the studies conducted until now focus either on theoretical reviews or surveys rather than on empirical findings and building appropriate models. This study contributes to the literature as it is one of the initial studies in Lebanon to develop a model for IFRS 9 based on empirical data. The preliminary evidence presented in the study suggests that it is a significantly important issue for future research. With an adjusted R-squared of $72 \%$, the explanatory power of the model constitutes a first step for future research, exploring additional variables and confirming the consistency of the results with other countries worldwide. 


\section{References}

Abad, J., \& Suarez, J. (2017) "Assessing the cyclical implications of IFRS 9 - a recursive model", available on-line at https://op.europa.eu/en/publicationdetail/-/publication/66c2edf9-8ec2-11e7-b92d-01aa75ed71a1/language-en Retrieved September 15, 2019

Baz, F. (2015) Bilanbanques 2015, Beirut: Bankdata Financial Services

Baz, F. (2017) Bilanbanques 2017, Beirut: Bankdata Financial Services

Baz, F. (2018) Bilanbanques 2018, Beirut: Bankdata Financial Services

Baz, F. (2019) Bilanbanques 2018, Beirut: Bankdata Financial Services

BCCL (Lebanon Banking Control Commission). (1999) "Financial disclosures and operations in financial markets, circular no. 66", available on-line at http://www.bccl.gov.lb., Retrieved July 15, 2019

BCCL (Lebanon Banking Control Commission). (2010) "Accounting for financial assets in light of the IFRS 9 requirements, circular no. 265", available online at http://www.bccl.gov.lb., Retrieved July 15, 2019

BCCL (Lebanon Banking Control Commission). (2015) "Retail loans classification and provisioning guidelines, circular no. 280", available on-line at http://www.bccl.gov.lb., Retrieved July 15, 2019

Bholat, D., Lastra, R.M., Markose, S.M., Miglionico, A., \& Sen, K. (2018) "Nonperforming loans at the dawn of IFRS 9: regulatory and accounting treatment of asset quality", Journal of Banking Regulation, vol. 19, no. 1: 33-54

Bushman, R.M., \& Williams, C.D. (2012) "Accounting discretion, loan loss provisioning, and discipline of banks' risk-taking", Journal of Accounting and Economics, vol. 54, no. 1: 1-18.

Casta, J. F., Lejard, C., \& Paget-Blanc, É. (2019) "The implementation of the IFRS 9 in banking industry", available on-line at https://hal.archivesouvertes.fr/hal-02405140/document, Retrieved March 24, 2021

CBL (Central Bank of Lebanon). (1999) "Financial transactions and operations in financial markets, circular no. 66" available on-line at http://www.bdl.gov.lb., Retrieved July 15, 2019

CBL (Central Bank of Lebanon). (2017) "Application of international financial reporting 9 (IFRS 9), circular no. 143" available on-line at http://www.bdl.gov.lb., Retrieved July 15, 2019

Chedid, O., \& Chaya, J. (2020) "The role of internal auditors to implement IFRS9: Case of Lebanese banks", Journal of Economics and International Finance, vol. 12, no. 1: 6-19

Cohen, B., \& Edwards, G. (2017) "The new era of expected credit loss provisioning", available on-line at https://www.bis.org/publ/qtrpdf/r_qt1703f.pdf, Retrieved July 15, 2019

Croatian National Bank (2018) "Banks Bulletin (31)", available on-line at https://www.hnb.hr/documents/20182/2561265/ebilten-o-bankama31.pdf/b1ec2e1b-fa07-49ce-bfef-6e04ca2739cc, Retrieved July 15, 2019 
Csaba, K. (2017) "Modelling of provision under new International Financial and Reporting Standard (IFRS 9)", available on-line at http://www.scseurope.net/dlib/2017/ecms2017acceptedpapers/0153-

fes_ECMS2017_0115.pdf, Retrieved July 15, 2019

Deloitte (2014) IFRS industry insights: Banking and securities sector, available online at https://www2.deloitte.com/content/dam/Deloitte/mt/Documents/ audit/ifrs-15-revenue-banking-and-securities-sector.pdf, Retrieved July 15, 2019

Deloitte (2014) "Fourth global IFRS banking survey; ready to land", available online at https://www2.deloitte.com/content/dam/Deloitte/ch/Documents/ financial-services/ch-en-financial-services-ifrs-fourth-global-bankingsurvey.pdf, Retrieved July 15, 2019

Deloitte (2015) "Fifth global IFRS banking survey: finding your way", available online at https://www2.deloitte.com/content/dam/Deloitte/global/Documents/ Financial-Services/gx-fsi-fifth-banking-ifrs-survey-full.pdf. Retrieved July 15, 2019

Deloitte (2016) "IFRS in focus: IFRS 9; financial instruments - high-level summary", available on-line at http://www.casplus.com/pubs/files/ IFRS $\% 20$ in $\% 20$ Focus $\% 20$ \%20IFRS\%209\%20high\%20level\%20summary.pdf, Retrieved July 15, 2019

Deloitte (2016) "Sixth global IFRS banking survey: No time like the present", available on-line at https://www2.deloitte.com/content/dam/Deloitte/global /Documents/Financial-Services/gx-fsi-sixth-ifrs-banking-survey.pdf, Retrieved July 15, 2019

Ernst \& Young. (2018) "Impairment of financial instruments under IFRS 9 Financial Intrsuments", available on-line at https://www.ey.com/en_gl/ifrs-technicalresources/impairment-of-financial-instruments-under-ifrs-9-financialinstruments, Retrieved July 15, 2019

Ernst \& Young (2018) "IFRS 9 impairment banking survey", available on-line at https://eyfinancialservicesthoughtgallery.ie/wp-

content/uploads/2018/08/EY-IFRS-9-impairment-banking-survey-2018FINAL.pdf, Retrieved July 15, 2019

Ertan, A. (2019) "Expected Losses, Unexpected Costs?" available on-line at https://ssrn.com/abstract=3504708, Retrieved March 24, 2021

European Banking Authority. (2016) "First observations on the impact and implementation of IFRS 9 by EU institutions", available on-line at https://www.eba.europa.eu/sites/default/documents/files/documents/10180/ 2087449/bb4d7ed3-58de-4f66-861e45024201b8e6/Report\%20on\%20IFRS\%209\%20impact\%20and\%20imple mentation.pdf, Retrieved July 15, 2019

European Banking Authority (2018) "Report on results from the EBA impact assessment of IFRS 9", available on-line at https://www.academia.edu/ 30612327, Retrieved July 15, 2019 
FB\&H (2018) "Information in the banking system entities of the Federation of Bosnia and Herzegovina as of 31.03.2018", available on-line at https://www.fba.ba/images/Publikacije_Banke/informacija_o_subjektima_ bankarskog_sistema_31032018_eng.pdf, Retrieved March 24, 2021

Fonseca, A.R., \& Gonzalez, F. (2008) "Cross-country determinants of bank income smoothing by managing loan-loss provisions", Journal of Banking and Finance, vol. 32, no. 2: 217-228

Frykström, N., \& Li, J. (2018) "IFRS 9-the new accounting standard for credit loss recognition", available on-line at https://www.riksbank.se/globalassets/ media/rapporter/ekonomiska-kommentarer/engelska/2018/ifrs-9--the-newaccounting-standard-for-credit-loss-recognition.pdf, Retrieved March 24, 2021

Gebhardt, G. (2016) "Impairments of Greek government bonds under IAS 39 and IFRS 9: A case study", Accounting in Europe, vol. 13, no. 2: 169-196

Ghasmi, H. M. (2016) "Deliberative and comparative study of international financial reporting standards IFRS 9", International Journal of Science Research and Technology, vol. 2, no. 2: 23-32

Greenawalt, M.G., \& Sinkey, J.F. (1988) "Bank Loan-Loss Provisions and the Income-Smoothing Hypothesis: An Empirical Analysis, 1976-1984", Journal of Financial Services Research, vol. 1, no. 4: 301-318

Gornjak, M. (2017) "Comparison of IAS 39 and IFRS 9: The analysis of replacement", International Journal of Management, Knowledge and Learning, vol. 6, no. 1: 115-130

Gornjak, M., (2020) "Literature Review of IFRS 9 and Its Key Parameters", Management, vol. 20: 22

Gornjak, M., 2020 "Literature Review of IFRS 9 and Its Key Parameters", available on-line at http://www.toknowpress.net/ISBN/978-961-6914-26-0/141.pdf, Retrieved March 24, 2021

Hashim, N., Li, W., \& O’Hanlon, J. (2016) "Expected-loss-based accounting for impairment of financial instruments: The FASB and IASB proposals 2009-2016", Accounting in Europe, vol. 13, no. 2: 229-267

Hoogervorst, H. (2014) "Closing the accounting chapter of the financial crisis", available on-line at https://cdn.ifrs.org/-/media/feature/news/speeches/2014/ hans-hoogervorst-march-2014.pdf, Retrieved July 15, 2019

Hoogervorst, H. (2016) "Introductory comments to the European Parliament", available on-line at https://cdn.ifrs.org/-/media/feature/news/speeches/2016/ hans-hoogervorst-introductory-comments-to-the-european-parliament-jan2016.pdf, Retrieved July 15, 2019

IFRS Foundation. (2003) "International accounting standard 8 accounting policies, changes in accounting estimates and errors, international accounting standards board", available on-line at https://www.ifrs.org, Retrieved July 15,2019

IFRS Foundation. (2014) "Project Summary IFRS 9 financial instruments", available on-line at https://www.ifrs.org., Retrieved July 15, 2019 
IFRS Foundation. (2014) "International financial reporting standard 9 financial instruments", available on-line at https://www.ifrs.org., Retrieved July 15, 2019

Kilic, E., Lobo, G.J., Ranasinghe, T., \& Sivaramakrishnan, K. (2013) "The Impact of SFAS 133 on income smoothing by banks through loan loss provisions", The Accounting Review, vol. 88, no. 1: 233-260

KPMG. (2015) "IFRS 9 creates specific challenges for insurers", available on-line at https://assets.kpmg/content/dam/kpmg/pdf/2016/06/8947-ifrs-9-insurerseng-web-f.pdf, Retrieved July 15, 2019

KPMG. (2018) "IFRS 9: Transition impact on banks in the Gulf Cooperation Council", available on-line at https://assets.kpmg/content/dam/kpmg/qa/ pdf/10/ifrs9-transition-impact-on-banks-in-the-gulf-cooperationcouncil.pdf, Retrieved July 15, 2019

Kund, A.G. \& Rugilo, D. (2018) "Does IFRS 9 Increase Financial Stability?", available on-line at https://ssrn.com/abstract $=3282509$ or http://dx.doi.org/10.2139/ssrn.3282509, Retrieved July 15, 2019

Lobo, G.J., \& Yang, D.H. (2001) "Bank managers' heterogeneous decisions on discretionary loan loss provisions", Review of Quantitative Finance and Accounting, vol. 16, no. 3: 223-250

Lu, Y. and Nikolaev, V.V. (2019) "Expected loan loss provisioning: An empirical model", available on-line at https://som.yale.edu/sites/default/files/files/ Lu\%20Nikolaev\%20Expected\%201oan\%20loss\%20provisioning.pdf, Retrieved March 24, 2021

Novotny-Farkas, Z. (2016) "The interaction of the IFRS 9 expected loss approach with supervisory rules and implications for financial stability", Accounting in Europe, vol. 13, no. 2: 197-227

Onali, E., \& Ginesti, G. (2014) "Pre-adoption market reaction to IFRS 9: A crosscountry event-study", Journal of Accounting and Public Policy, vol. 33, no. 6: 628-637

Onali, E., \& Ginesti, G. (2015) "New Accounting Rules for Loan Loss Provisions in Europe: Much Ado about Nothing?" available on-line at https://mpra.ub.unimuenchen.de/64467/3/MPRA_paper_64467.pdf, Retrieved 28 July, 2019

Orban, I., \& Tamimi, O. (2020) "Accounting model for impairment under IFRS 9 and its impact on loss allowance", European Research Studies Journal, vol. 23 , no. 4: $1259-1277$

PwC (2017) "IFRS 9 for banks; illustrative disclosures", available on-line at https://www.pwc.com/ee/et/home/majaastaaruanded/Illustrative_discloser_ IFRS_9_for_Banks.pdf, Retrieved July 15, 2019

Reitgruber, $\bar{W} . \overline{(2015)}$ "Methodological thoughts on expected loss estimation for IFRS 9 impairment: Hidden reserves, cyclical loss predictions and LGD backtesting", Credit Technology by Serasa Experian, vol. 92: 7-29

Salhi, Y., \& Thérond, P.E. (2017) "Alarm System for Credit Losses Impairment under IFRS 9", Bulletin Français d'Actuariat, vol. 17, no. 33: 131-161 
Seitz, B., Dinh, T., \& Rathgeber, A. (2018) "Understanding loan loss reserves under IFRS 9: a simulation-based approach", Advances in Quantitative Analysis of Finance and Accounting, vol. 16: 311-357

S\&P. (2017) "IFRS 9 Regional insights: 2017 EMEA market survey", available online at https://www.spglobal.com/marketintelligence/en/documents/miresearch-ifrs-9-regional-insights-emea-market-survey-2017.pdf, Retrieved July 15,2019

Sultanoğlu, B. (2018) "Expected credit loss model by IFRS 9 and its possible early impacts on European and Turkish banking sector", World of Accounting Science, vol. 20, no. 3: 476-506

Szücs, T., \& Márkus, G. (2020) "The impact of IFRS 9 impairment calculation on European banks' market rating", Economy and Finance: English-Language Edition of GAZDASÁG ÉS PENZÜGY, vol. 7, no. 3: 326-351

Tominac, S.B. and Vašiček, V. (2018) "The impact of IFRS 9 on loan impairments in Croatian banks", available on-line at from https://bib.irb.hr/ datoteka/963429.sanja_broztominacP.pdf, Retrieved July 15, 2019

World Bank (2016) "Financial Sector Assessment - Lebanon", available on-line at https://openknowledge.worldbank.org/bitstream/handle/10986/26018/Leba non-FSAP-Update-FSA-12222016.pdf? sequence $=1 \&$ isAllowed $=y$,

Retrieved July 15, 2019 